\title{
Fungal communities isolated from symptomatic naranjilla (Solanum quitoense Lam.) leaves in the Ecuadorian Amazon region
}

\section{Comunidades fúngicas aisladas de hojas sintomáticas de naranjilla (Solanum quitoense Lam.) en la región amazónica ecuatoriana} \author{
María Fernanda Dávila ${ }^{1}$, Wagner Chaves-Acuña ${ }^{1,2 *}$, Jeniffer Yánez ${ }^{1}$ \\ I Escuela de Ciencias Biológicas, Pontificia Universidad Católica del Ecuador, Apartado 17-01-2184, Quito, Ecuador \\ ${ }^{2}$ Escuela de Biología, Universidad de Costa Rica, San Pedro, 11501-2060, San José, Costa Rica \\ * Corresponding author e-mail: wchaves512@gmail.com; wchaves@veraguarainforest.com
}

https://doi.org/10.26807/remcb.v39i1.561

Recibido 11-12-2017; Aceptado 23-03-2018

\begin{abstract}
Fungal isolates were recovered from symptomatic naranjilla Solanum quitoense Lam. leaves sampled in the Pastaza province, an important productive region in the eastern Ecuadorian Amazon. Filamentous fungi were identified with molecular methods based on ITS sequencing. Among 68 recorded fungi, the isolation of mycobiota resulted in 14 taxa. Diaporthe citri, D. schini, and Xylaria berteri were the most frequently isolated species. To our knowledge, more than $90 \%$ of the taxa recovered in this study are reported for the first time in $S$. quitoense. Diversity indices suggest that symptomatic tissues represent a moderately diverse reservoir for fungal communities. This is the first study to characterize fungal diversity associated with symptomatic naranjilla leaves showing necrosis or chlorosis tissues through ITS sequencing. The findings presented in this study are relevant, as they can assist in the isolation of a great number of fungal taxa, which could potentially harbor a broad diversity of plant-derived natural molecules with biologically active substances.
\end{abstract}

KEYWORDS: Endophytic fungi, ITS-sequencing, Lulo, Mycobiota, rDNA

RESUMEN.- Se recuperaron aislados de tejidos sintomáticos de hojas de naranjilla Solanum quitoense Lam. en la provincia de Pastaza, una zona de producción importante de la región amazónica del Ecuador. Se identificaron hongos filamentosos por medio de técnicas moleculares basados en la secuencia de la región ITS. De un total de 68 hongos, se identificaron 14 taxa. La mayor cantidad de registros pertenecieron a las especies Diaporthe citri, D. schini, y Xylaria berteri. Según lo que conocemos, más del $90 \%$ de los taxones recuperados en este estudio se reportan por primera vez en $S$. quitoense. Los índices de diversidad sugieren que los tejidos sintomáticos representan un reservorio moderadamente diverso para comunidades de hongos. Este estudio es el primero en caracterizar la diversidad fúngica asociada con hojas sintomáticas que presentan tejidos necróticos o cloróticos en naranjilla. Los resultados de este estudio son relevantes, ya que aportan a la obtención de un gran número de especies de hongos que, potencialmente, podrían albergar una gran diversidad de moléculas naturales derivadas de plantas con sustancias de actividad biológica.

PALABRAS CLAVES: ADNr, Hongos endófitos, ITS, Lulo, Micobiota

\section{INTRODUCTION}

The naranjilla plant, or lulo (Solanum quitoense Lam.), is a tropical Solanaceae widely consumed in Peru, Ecuador, Colombia and Central America and in high demand at agro-industrial markets throughout the region (Flórez et al. 2008; Pulido et al. 2008; Acosta et al. 2009; Granados et al. 2013). The crop is native to the Andean foothills and has highly ramified cylindrical stems, with lar- ge oval shaped leaves (León 2000). In spite of its natural mechanical defenses (e.g., spine-covered leaves) and the use of fertilizers, fungicides, and bio-control agents (Revelo et al. 2010), a series of studies report a broad list of pathogenic fungi, such as Phytophthora infestans, Sclerotinia sclerotiorum, Fusarium oxysporum, Colletotrichum spp. and Cladosporium spp., which cause several detrimental diseases that affect naranjilla (Montes-Rojas et al. 2010; Revelo et al. 2010). There is a wide array of 
farmer-selected varieties of the naranjilla (Casierra-Posada et al. 2004), and most cultivation practices (e.g., sanitary pruning) rely on empirical approaches based on local knowledge, with no experimental research support to fully understand and control plant pathogens (Montes-Rojas et al. 2010; Revelo et al. 2010).

Fungal communities have adapted to an extensive array of environments with distinctive physiological requirements that impact species diversity and colonization (Petrini 1996; Schadt et al. 2003; Opik et al. 2006; Das et al. 2007; Mondal et al. 2007; Frohlich-Nowoisky et al. 2009). To date, fungi inhabiting vegetative tissues have been isolated from a considerable variety of plant species, in both temperate (Jumpponen and Jones 2009; Sánchez-Márquez et al. 2010; Ghimire et al. 2011; Gonzalez and Tello 2011; Koukol et al. 2012) and tropical regions (Frohlich et al. 2000; Photita et al. 2001; Suryanarayanan et al. 2005; Arnold and Lutzoni 2007; Thomas et al. 2008; Gazis and Chaverri 2010; Vega et al. 2010; Rivera-Orduña et al. 2011; Vaz et al. 2014); however, their ecological roles and abundance may vary depending on the host or tissue they are found to inhabit (Johnston et al. 2006; Sieber 2007).

Fungal microorganisms that colonize healthy plant tissues without causing adverse symptoms have been defined as endophytes (Carroll 1986; Petrini 1991; Hallmann et al. 1997; Hyde and Soytong 2008); however, previous studies have shown that apparently benign species may subsequently shift their ecological role to pathogens or saprobes due to environmental stress factors (e.g., nutrient deficiency, drought, heat) (Photita et al. 2004; Agrios 2005; Cakmak 2005; Promputtha et al. 2007). For example, latent pathogens of the genus Colletotrichum are known to live innocuously within healthy tissues prior to showing of symptoms (Cerkauskas 1988; Prihastuti et al. 2009), while an endophytic stage might be of relevant importance within the life cycle of tropical pathogens (for example, Deightoniella torulosa in Musa acuminata Photita et al. 2004). On the other hand, the mycobiota is likely to vary depending on the host (Arnold and Herre 2003). For instance, some species of the genus Diaporthe may act as pathogens in some hosts (Santos et al. 2011), and as endophytes in others (Sebastianes et al. 2011). Hence, the impact of fungal communities on plant species may be overlooked (Omacini et al. 2001).

Our understanding of fungal communities has benefited from an increasing number of fungal strains and species isolated from tropical crops of economic importance (Zhu et al. 2000; Sánchez-Márquez et al. 2007). Among plant aerial tissues, diseased leaves showing necrotic symptoms or chlorotic tissues represent a vulnerable interface between plants and their surroundings, where complex fungi communities grow within ever-changing environments (Arnold et al. 2003). In particular, changes within the inner biochemical milieu increase the vulnerability of symptomatic leaves as potential reservoirs for high fungal assemblages through wounds (Schulz and Boyle 2006). Recent studies show that several species within the mycobiome might be isolated from both dead and living plant material (U'Ren et al. 2010; Osono and Hirose 2011; Yuan and Chen 2014; U'Ren and Arnold 2016). Yet, while previous studies have used molecular characters to identify fungal communities inhabiting tropical plants (Crozier et al. 2006; Sieber 2007; Rungjindamai et al. 2008; Thomas et al. 2008; Gazis and Chaverri 2010; Mohamed et al. 2010; Abreu et al. 2012; Vaz et al. 2014), little is known about the fundamental aspects derived from ecological approaches in fungi associated with symptomatic foliar tissues.

In light of the growing interest in the study of microbial communities and interspecific associations in plant biology (Backman and Sikora 2008), and considering that necrotic lesions are detrimental to the fruit production demanded for agro-industrial crops (De Lucca 2007), this study aims to identify the fungal community inhabiting symptomatic foliar tissues of $S$. quitoense showing necrotic symptoms or chlorotic tissues, collected in the eastern Ecuadorian Amazon region. The study of microbial fungi in diseased leaves is, in turn, expected to present an alternative to isolate native fungal species with potential medicinal and pharmaceutical properties.

\section{MATERIALS AND METHODS}

Study site and sample collection.- This research was conducted in plantations of a wild variety of naranjilla (S. quitoense cv. quitoense) in the Pastaza province, in the eastern Amazon region of Ecuador ( $1^{\circ} 28^{\prime} 12.821^{\prime \prime}$ S, 72 ${ }^{\circ} 5^{\prime} 45.986$ " W, 1115 m.a.s.1.). Mature plants of about 1-2 $\mathrm{m}$ in height were randomly sampled when precipitations reached their first annual peak during May of 2015, in a 1 hectare crop. One leaf per plant showing symptomatic tissues with necrosis was collected. Twenty samples were transported to the laboratory in sterile plastic bags and stored for 24 to $48 \mathrm{~h}$ at $4{ }^{\circ} \mathrm{C}$ until the fungi was isolated (Agrios 2005).

Isolation of fungi.- In total, four leaf segments $(1 \times 1$ $\mathrm{cm})$ per leaf were taken from symptomatic tissue and were used for the isolation of fungi according to protocols modified from the method described by Crous et al. (2009). To induce sporulation, samples were surface-disinfected through immersion in 70\% ethanol $(1 \mathrm{~min})$ and $10 \%$ sodium hypochlorite ( $5 \mathrm{~min})$. Samples were washed 
in sterile water three times before transferring leaf segments to Petri dishes $(90 \mathrm{~mm}$ ) containing a sterile Potato Dextrose Agar (PDA, Difco Laboratories, Detroit, MI) supplemented with chloramphenicol $30 \mathrm{ppm}$ to suppress bacterial proliferation, following Crous et al. (2009). The plates were incubated at $20-27^{\circ} \mathrm{C}(12-\mathrm{h}$ light/12-h dark regime) and checked regularly for fungal growth for two weeks. After hyphal tips emerged from the leaf tissue, different mycelium fragments were subcultured onto new Petri dishes with the same media, for further purification and identification (Crozier et al. 2006). Filamentous fungal isolates were morphologically evaluated and divided into morphotypes based on macroscopic observation of colonies and microscopic identification of reproductive structures such as distinctive spores (Crous et al. 2009)

DNA extraction.- About $40 \mathrm{mg}$ of fresh fungal tissue was disrupted using a sterile blade, and genomic DNA was extracted using the Wizard Genomic DNA Purification Kit (Promega, Madison, WI) in accordance with manufacturer's instructions. DNA concentration was quantified with a spectrophotometer (Nanodrop Technologies, Rockland, Denmark) and stored at $-20^{\circ} \mathrm{C}$.

PCR amplification.- The DNA was amplified using primer pairs for the internal transcribed spacer region (ITS) of rDNA, ITS4 (5'-TCCTCCGCTTATTGATATGC-3') and ITS5 (5'-GGAAGTAAAAGTCGTAACAAGG-3'), commonly used for fungal barcoding (White et al. 1990), and GoTaq Green Master mix (Promega, Madison, WI) according to manufacturer's protocol. Reactions were carried out in $25 \mu \mathrm{l}$ final volume under the following conditions: the initial denaturation step at $94{ }^{\circ} \mathrm{C}$ for 5 min, followed by 35 cycles at $94{ }^{\circ} \mathrm{C}$ for $30 \mathrm{~s}, 55^{\circ} \mathrm{C}$ for $30 \mathrm{~s}, 72{ }^{\circ} \mathrm{C}$ for $30 \mathrm{~s}$, and a final elongation at $72{ }^{\circ} \mathrm{C}$ for $10 \mathrm{~min}$. All amplifications performed included a positive control containing $3 \mu \mathrm{l}$ of fungal DNA and a negative control containing $1.5 \mu \mathrm{l}$ of master mix. PCR products were visualized with $1.5 \mu \mathrm{l}$ of $100 \mathrm{bp}$ ladder by electrophoresis on a $2.5 \%(\mathrm{w} / \mathrm{v})$ agarose gel containing Sybr Safe (Invitrogen, Mulgrave, Australia) under UV light. Amplification products were sequenced at a commercial laboratory (Macrogen, Seoul, South Korea).

Fungal identification.- To identify the fungal isolates based on ITS sequence, the consensus sequences were subjected to the BLASTn search with the National Center for Biotechnology Information (NCBI, Bethesda, MD) database. Multiple sequence alignment was performed using CLUSTAL W version 1.8 (Thompson et al. 1994). Query coverage and identities were calculated using MEGA Version 6.0 (Tamura et al. 2013). Fungal species were defined using an ITS region identity threshold of $98 \%$ to sequences deposited in GenBank. All ITS sequences obtained in this work were deposited in
GenBank under the accession numbers: MF185318MF185359. Fungal classification follows the MycoBank (http://www.mycobank.org) database.

Statistical analysis.- Colonization frequency (CF) was calculated as the number of discs colonized by a given fungus divided by the total number of discs in that sample, expressed as percentages following the method of Hata and Futai (1995). Relative frequency of isolation (RF) was determined as the total number of discs colonized by a given taxon divided by the total number of taxa obtained from molecular analyses. Fungal species diversity was estimated using PAST, version 1.9 (Paleontological Statistics) software (Hammer et al. 2001) considering Simpson's index to quantify species dominance (Simpson 1949), Shannon's index to estimate species diversity (Shannon and Weaver 1963), and Margalef's index to assess species richness using the following formulas:

$$
\begin{array}{ll}
\text { 1. } & \text { Simpson's diversity }(1-\mathrm{D})=1-\Sigma(\mathrm{pi})^{2} \\
\text { 2. } & \text { Shannon-Wiener index }\left(\mathrm{H}^{\prime}\right)=-\Sigma \mathrm{pi}\left(\log _{2} \mathrm{p}_{\mathrm{i}}\right) \\
\text { 3. } & \text { Margalef's }\left(\mathrm{D}^{\mathrm{mg}}\right)=(\mathrm{S}-1) / \ln \mathrm{N}
\end{array}
$$

where, pi was the proportion of colonization frequency of a given taxon in diseased tissue samples, $\mathrm{S}$ is the total number of taxa isolated from diseased foliar tissue samples, and $\mathrm{N}$ is the number of species recorded.

\section{RESULTS}

A total of 68 fungal isolates were recovered from symptomatic foliar tissues of $S$. quitoense. Isolated fungi belonged to the phyllum Ascomycota, distributed in four orders: Diaporthales, Glomerellales, Sordariales, and Trichosphaeriales. Fungal isolates comprised four families, six genera and 14 identified taxa based on molecular methods (Table 1). Query coverage ranged from $93-99 \%$ within our sampled fungal community, except from a single isolate of a possibly Xylaria species, which scored $88 \%$. Fungal communities presented a low overall isolation rate of $5.75 \%$. The most frequently isolated fungi were Diaporthe citri, D. schini, and Xylaria berteri, which accounted for the highest relative frequency, and each presented $\mathrm{a} \geq 10 \%$ isolation rate (Table 2). Among the total fungal isolates, four taxa $(28.5 \%)$ occurred as singlets ( $\leq 2$ isolates), including Diaporthe, Nemania, and Phomopsis colonies. Diaporthe, Phomopsis, and Xylaria were the most frequently recovered genera (Table 3 ). Diversity indices displayed high values regarding species dominance (1-D $=0.894)$, diversity $\left(\mathrm{H}^{\prime}=3.376\right)$, and richness $\left(\mathrm{D}^{\mathrm{mg}}=\right.$ 3.07). 
Table 1. ITS-based identification of fungal isolates recovered from symptomatic leaves of Solanum quitoense in the Ecuadorian Amazon.

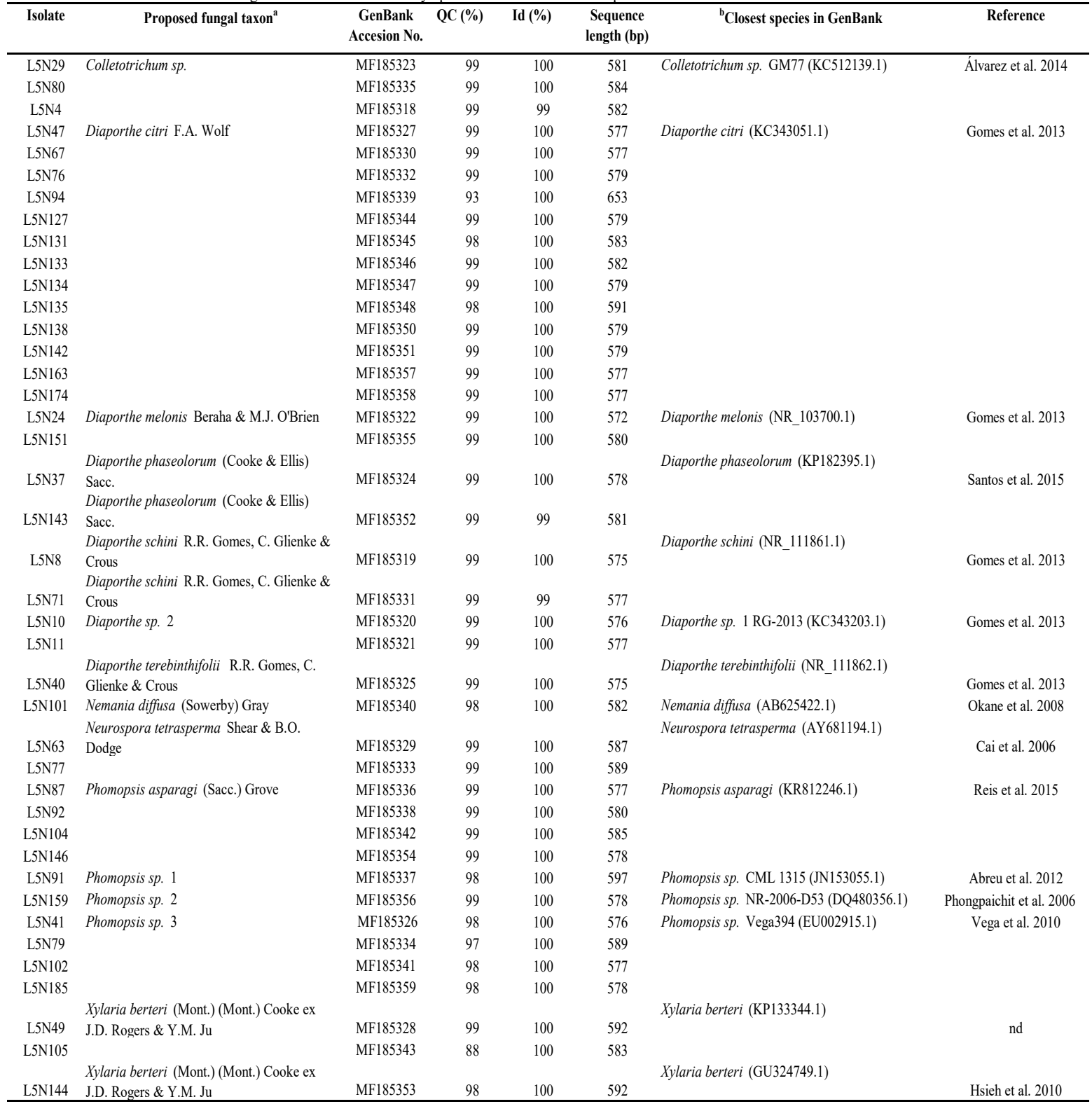

${ }^{a}$ Taxonomic identification of fungal isolates was conducted using amplification of ITS4 and ITS5 by PCR. All sequences were deposited in the NCBI GenBank (Accession No. column). QC: query cover, Id: identity. b Sequences available in GenBank used for comparisons with sequences obtained in this study via BLAST software. 
Table 2. Total number of isolates, isolation rate (\%) and relative frequency of ascomycetous fungi recovered from symptomatic foliar tissues of Solanum quitoense in the Ecuadorian Amazon.

\begin{tabular}{|c|c|c|c|}
\hline Taxa & No. isolates & Isolation rate (\%) & Relative Frequency \\
\hline \multicolumn{4}{|l|}{ Diaporthales } \\
\hline Diaporthe citri & 15 & 18.75 & 1.0000 \\
\hline Diaporthe melonis & 4 & 5 & 0.2667 \\
\hline Diaporthe phaseolorum & 5 & 6.25 & 0.3333 \\
\hline Diaporthe schini & 10 & 12.5 & 0.6667 \\
\hline Phomopsis asparagi & 5 & 6.25 & 0.3333 \\
\hline Phomopsis sp. 3 & 4 & 5 & 0.2667 \\
\hline \multicolumn{4}{|l|}{ Glomerellales } \\
\hline Colletotrichum sp. & 3 & 3.75 & 0.2000 \\
\hline \multicolumn{4}{|l|}{ Sordariales } \\
\hline Neurospora tetrasperma & 5 & 6.25 & 0.3333 \\
\hline \multicolumn{4}{|l|}{ Trichosphaeriales } \\
\hline Xylaria berteri & 10 & 12.5 & 0.6667 \\
\hline
\end{tabular}

\section{DISCUSSION}

In the Tropics, research on fungi associated with the plant's internal tissues has gained greater attention, considering that ecological relationships with photosynthetic organisms comprise a wide variety of fungal species (Petrini 1991; Bills 1996; Saikkonen et al. 2004; Arnold and Lutzony 2007; Oono et al. 2015). Previous works have reported Ascomycota as the dominant phyllum within fungi inhabiting foliar plant tissues (Arnold and Lutzoni 2007; Vaz et al. 2014). This work represents the first attempt to characterize fungal diversity associated with symptomatic naranjilla foliar tissue using molecular approaches through ITS sequencing. Typically, the identification of fungal species lacks morphological variation, while in molecular approaches, the amplification of commonly used regions (e.g. mitochondrial cytochrome c oxidase subunit 1) is often complicated and not variable enough (Crouch et al. 2017). However, previous studies on fungal taxonomy have proposed the ITS region as the primary fungal barcode marker (Schoch et al. 2012) given its high probability for correctly identifying fungal species through a measure of genetic distances (Del-Prado et al. 2010). We identified 14 ascomycetous fungal taxa. Results showed that D. citri, D. schini, and $X$. berteri were the species most frequently isolated from symptomatic foliar tissues of naranjilla in the eastern Ecuadorian Amazon region. Recent studies based on ITS sequencing have been shown to yield misleading species diagnoses in fungi associated with grass, particularly for the Colletotrichum species complex. The latter might explain the unknown Colletotrichum taxa isolated in this study. We strongly recommend the use of metagenomic and small-subunit RNA-based sequence analysis techniques for future research, as this has previously been validated as an accurate estimator of microbial assessments when evaluating species richness and evenness (Fierer et al. 2007).

In previous studies, several pathogenic fungal species have been reported in cultivated and wild naranjilla such as Botrytis sp., Cercospora sp., Cladosporium sp., Colletotrichum spp., Fusarium oxysporum, Phytophthora infestans, Rhizoctonia solani, Sclerotinia

Table 3. Number of isolates and species per genus recovered in symptomatic leaves of Solanum quitoense in the Ecuadorian Amazon

\begin{tabular}{ccc}
\hline Genus & No. isolates & No. Species \\
\hline Colletotrichum & 3 & 1 \\
Diaporthe & 37 & 6 \\
Neurospora & 5 & 1 \\
Nemania & 1 & 1 \\
Phomopsis & 12 & 4 \\
Xylaria & 10 & 1 \\
\hline
\end{tabular}


sclerotiorum, and Septoria solanicola (Rogg 2000; Quinchia and Cabrera 2006; Montes-Rojas et al. 2010; Revelo et al. 2010). from which only Colletotrichum colonies were identified in our work. To our knowledge, nine taxa isolated in this study, D. citri, D. melonis, $D$. phaseolorum, D. schini, D. terebinthifolii, Phomopsis asparagi, Neurospora tetrasperma, Nemania diffusa, and $X$. berteri, have not previously been reported for S. quitoense. Also, isolates of Diaporthe $(\mathrm{n}=2)$ and Phomopsis $(\mathrm{n}=3)$ could not be identified to the species level. Both of these genera comprise highly complex taxa with a considerable amount of cryptic species that have yet to be described (Gomes et al. 2013). In this study, one isolate (L5N105) proved to be genetically distinct from its closest match in GenBank database. Although the latter may suggest that these isolates could represent unknown species, further morphological and molecular assessments are needed.

Fungal communities are known to have high species diversity in the tropics, as the incidence of fungi within foliar tissues tends to increase with decreasing latitude (Arnold and Lutzoni 2007). In our study, fungal species found within symptomatic naranjilla tissues showed a low overall isolation rate. This may be due to the sampling period, as the aerial tissues of plants may be less vulnerable to internal colonization when heavy rains and high humidity occur (Photita et al. 2001). Our results coincide with previous work on other fungal communities in tropical plants (Frohlich et al. 2000; Arnold and Lutzoni 2007), where fungal assemblages have been described to show a pattern of few common species and a dominance by rare species. While the current study shows high values of species dominance and diversity and richness among the fungal communities found within diseased foliar tissues of naranjilla plants, our results may not show the most common fungal species, but rather colonies that grow rapidly under the isolation methods applied in this study, such as the PDA medium and the 12-h light/12-h dark regime (Arnold and Lutzoni 2007; Sánchez-Márquez et al. 2007).

Diversity indices calculated in this work suggest that leaves presenting necrotic lesions may in fact represent a moderately rich ecosystem for fungal communities (1-D $\left.=0.894 ; \mathrm{H}^{\prime}=3.376 ; \mathrm{D}^{\mathrm{mg}}=3.07\right)$. Several of the fungal species recovered here, including Diaporthe spp. (Zhang et al. 1999; Santos et al. 2011; Sebastianes et al. 2012), Phomopsis spp. (Zhang et al. 1999; Koh et al. 2005) and Colletotrichum sp. (Hyde et al. 2009; Wikee et al. 2011; Cannon et al. 2012) have been previously reported as pathogens from many plant taxa. However, we cannot assure the ecological role of the fungi isolated here, as we did not assess if isolates were acting as endophytes, saprobes, or parasites given that the natural behavior of fungal species may be influenced by environmental conditions and/or interspecific relationships (Millar 1980; Viret and Petrini 1994; Williamson 1994; Wilson 1995; Promputtha et al. 2007). In addition to this, a great number of fungal species may act as secondary colonizers of necrotic leaf tissues, including soil saprophytes (Aegerter et al. 2000; Bruez et al. 2014; Peay et al. 2016). We recommend conducting Koch's postulates in future studies to determine fungal phytopatogenecity activity.

In general, although the majority of fungal community studies have focused on endophytes isolated from asymptomatic tissues, this work identifies fungal organisms capable of surviving within symptomatic leaves. The findings presented in this study are relevant because they can lead to assisting in the isolation of a great number of fungal taxa, which could potentially harbor a broad diversity of plant-derived natural molecules with biologically active substances (Schulz et al. 2002; Kharwar et al. 2011). Recent studies confirm a growing interest in isolating mycobiota for novel compounds (Dreyfuss and Chapela 1994; Dettrakul et al. 2003; Kobayashi et al. 2003; Kumar and Hyde 2004; Tejesvi et al. 2007). Furthermore, based on the premise that plant-fungi interactions have evolved over the course of a long evolutionary process, some fungal species have been shown to mimic the host compounds in the metabolites produced (Strobel 2002). Further studies on the chemical composition and medicinal properties of the mycobiome in $S$. quitoense are required to determine their potential in producing bioactive metabolites. The latter may, in turn, be relevant to the biocontrol agents of other fungal phytopatogens by contending for the same ecological niche (Asiegbu et al. 2005; Brum et al. 2012).

We highly encourage the direct sequencing of leaves as a culture-free method to assess species diversity and composition in future studies (Arnold 2007), given that the fungal diversity of symptomatic tissues of $S$. quitoense may be greater than that reported here. Furthermore, isolating fungal microbes from other aerial tissues (e.g. stems, flowers, fruits) and comparing the different varieties of naranjilla cultivars is also encouraged. Even though symptomatic leaves may act as potential reservoirs for latent pathogens (Andersen and Walker 1985; Schulz and Boyle 2006), the modes of inter-specific interactions and the pathogenicity of fungal species remains to be demonstrated. A comparison between both symptomatic and asymptomatic tissues might provide a broader perspective regarding the diversity succession of fungal species when diseased leaves occur.

\section{ACKNOWLEDGMENTS}

This research was funded by the Pontificia Universidad 
Católica del Ecuador. We would like to thank Raúl Jaramillo and Emilia Moreno for their helpful comments and suggestions. We also thank the two anonymous reviewers for their constructive comments and their thorough review of the manuscript. The authors have no conflict of interest to declare.

\section{REFERENCES}

Abreu LM, Costa SS, Pfenning LH, Takahashi JA, Larsen TO, Andersen B. 2012. Chemical and molecular characterization of Phomopsis and Cytospora-like endophytes from different host plants in Brazil. Fungal Biol. 116: 249-260.

Acosta A, Perez F, Vaillant F. 2009. Chemical characterization, antioxidant properties, and volatile constituents of naranjilla (Solanum quitoense Lam.) cultivated in Costa Rica. Arch Latinoam Nutr. 59: 88-94.

Aegerter BJ, Gordon TR, Davis RM. 2000. Occurrence and pathogenicity of fungi associated with melon root rot and vine decline in California. Plant Dis. 84: 224-230.

Agrios GN. 2005. Plant Pathology, 5th edition. London: Elsevier Academic Press. 922 p.

Álvarez E, Gañán L, Rojas-Trivino A, Mejia JF, Llano GA, González A. 2014. Diversity andpathogenicity of Colletotrichum species isolated from soursop in Colombia. Eur J Plant Pathol. 139: 325-338.

Andersen RN, Walker HL. 1985. Colletotrichum coccodes: A pathogen of eastern black nightshade (Solanum ptycanthum). Weed Sci. 33: 902-905.

Arnold AE. 2007. Understanding the diversity of foliar endophytic fungi: progress, challenges, and frontiers. Fungal Biol Rev. 21: 51-66.

Arnold AE, Herre EA. 2003. Canopy cover and leaf age affect colonization by tropical fungal endophytes: ecological pattern and process in Theobroma cacao (Malvaceae). Mycologia. 95:388-398.

Arnold AE, Mejía LC, Kyllo D, Rojas EI, Maynard Z, Robbins N, Herre EA. 2003. Fungal endophytes limit pathogen damage in a tropical tree. PNAS. 26: 15649-15654.

Arnold AE, Lutzoni F. 2007. Diversity and host range of foliar fungal endophytes: are tropical leaves biodiversity hotspots? Ecology. 88: 541-549.

Asiegbu FO, Adomas A, Stenlid JA. 2005. Conifer root and butt rot caused by Heterobasidion annosum (Fr.) Bref. sl. Mol Plan Pathol. 6: 395-409.
Backman PA, Sikora RA. 2008. Endophytes: an emerging tool for biological control. Biol Control. 46:1-3.

Bills GF. 1996. Isolation and analysis of endophytic fungal communities from woody plants. In: Redlin S, LM Carris, editors. Systematics, Ecology and Evolution of Endophytic Fungi in Grasses and Woody Plants. St Paul, USA: MNAPS Press. p. 31-65

Bruez E, Vallance J, Gerbore J, Lecomte P, Da Costa JP, Guerin-Dubrana L, Rey P. 2014. Analyses of the temporal dynamics of fungal communities colonizing healthy wood tissues of esca leaf-symptomatic and asymptomatic vines. Plos One. 9: e95928.

Brum MCP, Araujo WL, Maki CS, Azevedo JLD. 2012. Endophytic fungi from Vitis labrusca L. ('Niagara Rosada') and its potential for the biological control of Fusarium oxysporum. Genet Mol Res. 11: 4187-4197.

Cai L, Jeewon R, Hyde KD. 2006. Phylogenetic investigations of Sordariaceae based on multiple gene sequences and morphology. Mycol Res. 110: 137-150.

Cakmak I. 2005. The role of potassium in alleviating detrimental effects of abiotic stresses in plants. J Plant Nutr Soil Sci. 168: 521-530.

Cannon PF, Damm U, Johnston PR, Weir BS. 2012. Colletotrichum - current status and future directions. Stud Mycol. 73: 181-213.

Carroll GC. 1986. The biology of endophytism in plants with particular reference to woody perennials. In: Fokkema NJ, van den Heuvel J, editors. Microbiology of phyllosphere. London: Cambridge University Press. p. 205-222.

Casierra-Posada F, García EJ, Ludders P. 2004. Determinación del punto óptimo de cosecha en el lulo (Solanum quitoense Lam.) var. quitoense y septentrionale. Agron. Colomb. 2: 3239.

Cerkauskas RF. 1988. Latent colonization by Colletotrichum spp.: epidemiological considerations and implications for mycoherbicides. Can J Plant Pathol. 10: 297-310.

Crouch JA, Clarke BB, Hillman BI. 2009. What is the value of ITS sequence data in Colletotrichum systematics and species diagnosis? A case study using the falcate-spored graminicoulous Colletotrichum group. Mycologia. 101: 648-656.

Crous PW, Verkley GJ, Groenewald E, Samson RA. 2009. CBS Laboratory Manual Series 1: Fungal Biodiversity. The Netherlands, Central Bureau voor Schimmelcultures. 
Crozier J, Thomas SE, Aime MC, Evans HC, Holmes KA. 2006. Molecular characterization of fungal endophytic morphospecies isolated from stems and pods of Theobroma cacao. Plant Pathol. 55: 783-791.

Das M, Rover TV, Left LG. 2007. Diversity of fungi, and actinomycetes on leaves decomposing in a stream. Appl. Environ. Microbiol. 73: 756-767.

De Lucca AJ. 2007. Harmful fungi in both agriculture and medicine. Rev Iberoam Micol. 24: 3-13.

Del-Prado R, Cubas P, Lumbsch HT, Divakar PK, Blanco O, de Paz GA, Molina MC, Crespo A. 2010. Genetic distances within and among species in monophyletic lineages of Parmeliaceae (Ascomycota) as a tool for taxon delimitation. Mol Phylogenet Evol. 56: 125-133.

Dettrakul S, Kittakoop P, Isaka M, Nopuchal S, Suyarnsestakorn C, Tanticharoen M, Thebtaranonth Y. 2003. Antimycobacterial pimarane diterpenes from the Fungus Diaporthe $s p$. Bioorg Med Chem Lett. 13:1253-1255

Dreyfuss MM, Chapela IH. 1994. Potential of fungi in the discovery of novel, low-molecular weight pharmaceuticals. In: Gullo V, editor. Discovery of Novel Natural Products with Therapeutic Potential. Newnes. p. 49-80.

Fierer N, Breitbart M, Nulton J, Salamon P, Lozupone C, Jones R, Robeson M, Edwards RA, Felts B, Rayhwak S, Knight R. 2007. Metagenomic and smallsubunit rRNA analyses reveal the genetic diversity of bacteria, archaea, fungi, and viruses in soil. Appl Environ Microbiol. 73: 7059-7066.

Flórez SL, Lastrilla DM, Chaves B, Fisher G, Magnitskiy S. 2008. Growth of lulo (Solanum quitoense L.) plants affected by salinity and substrate. Rev Bras Frutic. 30: 402-408.

Frohlich J, Hyde KD, Petrini O. 2000. Endophytic fungi associated with palms. Mycol Res. 104: 1201-1212.

Frohlich-Nowoisky J, Pickersqill DA, Després VR, Poschl u. 2009. High diversity of fungi in air particulate matter. Proc. Natl. Acad. Sci. USA. 106: 12814-9.

Gazis R, Chaverri P. 2010. Diversity of fungal endophytes in leaves and stems of wild rubber trees (Hevea brasiliensis) in Peru. Fungal Ecol. 3: 240-254.

Ghimire SR, Charlton ND, Bell JD, Krishnamurthy YL, Craven KD. 2011. Biodiversity of fungal endophyte communities inhabiting switchgrass (Panicum virgatum L.) growing in the native tallgrass prairie of northern Oklahoma. Fungal Divers. 47: 19-27.
Gomes RR, Glienke C, Videira SI, Lombard L, Groenewald JZ, Crous PW. 2013. Diaporthe: a genus of endophytic, saprobic, and plant pathogenic fungi. Persoonia. 31: 1-41.

González V, Tello ML. 2011. The endophytic mycota associated with Vitis vinifera in central Spain. Fungal Divers. 47: 2942.

Granados C, Torrenegra ME, Acevedo D, Romero P. 2013. Evaluación fisicoquímica y microbiolpogica del aperitivo vínico de lulo (Solanum quitoense L.). Inf. Tecnol. 24: 35-40.

Hallmann J, Quadt-Hallmann A, Mahaffee WF, Kloepper JW. 1997. Bacterial endophytes in agricultural crops. Can J Microbiol. 43: 895-914.

Hammer Ø, Harper DAT, Ryan PD. 2001. PAST: Paleontological statistics software package for education and data analysis. Palaeontol Electron. 4: 9.

Hata K, Futai K. 1995. Endophytic fungi associated with healthy pine needles and needles infested by the pine needle gall midge, Thecodiplosis japonensis. Cana J Bot. 73: 384-390.

Hsieh HM, Lin CR, Fang MJ, Rogers JD, Fournier J, Lechat C, Ju YM. 2010. Phylogenetic status of Xylaria subgenus Pseudoxylaria among taxa of the subfamily Xylarioideae (Xylariaceae) and phylogeny of the taxa involved in the subfamily. Mol Phylogenet Evol. 54: 957-969.

Hyde KD, Soytong K. 2008. The fungal endophyte dilemma. Fungal Divers. 33: 163-173.

Hyde KD, Cai L, Cannon PF, Crouch J, Crous PW, Damn U, Goodwin PH, Chen H, Johnston PR,

Jones EBG, et al. 2009. Colletotrichum - names in current use. Fungal Divers. 39: 147-182.

Johnston PR, Sutherland PW, Joshee S. 2006. Visualizing endophytic fungi within leaves by detection of (1-3) B-D-glucans in fungal cell walls. Mycologist 20: 159-162.

Jumpponen A, Jones KL. 2009. Massively parallel 454 sequencing indicates hyperdiverse fungal communities in temperate Quercus macrocarpa phyllosphere. New Phytol. 184: 438-448.

Kharwar RN, Mishra A, Gond SK, Stierle A, Stierle D. 2011. Anticancer compounds derived from fungal endophytes: their importance and future challenges. Nat Prod Rep. 28:1208-28.

Kobayashi H, Meguro S, Yoshimoto T, Namikoshi M. 2003. Absolute structure, biosynthesis, and anti-microtubule activity of phomopsidin, isolated from a marine derived fungus Phomopsis sp. Tetrahedron. 59: 455-459. 
Koh YJ, Hur JS, Jung JS. 2005. Postharvest fruit rot of kiwifruit (Actinidia deliciosa) in Korea. N Z J Crop Hortic Sci. 3: 303-310.

Koukol O, Kolarik M, Kolarova Z, Baldrian P. 2012. Diversity of foliar endophytes in wind-fallen Picea abies trees. Fungal Divers. 54: 69-77.

León J. 2000. Botánica de los cultivos tropicales, 3rd Edition. Costa Rica: Agroamérica. 522 p.

Millar CS. 1980. Infection processes on conifer needles. In: Blakeman JP, editor. Microbial ecology of the phylloplane. London: Academic Press. p 185-209.

Mohamed R, Jong PL, Zali MS. 2010. Fungal diversity in wounded stems of Aquilaria malaccensis. Fungal Divers. 43: $67-74$.

Mondal SN, Vicent A, Reis RF, Timmer LW. 2007. Saprophytic colonization of citrus twigs by Diaporthe citri and factors affecting pycnidial production and conidial survival. Plant Dis. 91: 387-392.

Montes-Rojas C, Muñoz LA, Terán VF, Prado FA, Quinónez MA. 2010. Pathogenity evaluation on Solanum quitoense Lam. Clones. Acta Agron. 59: 144-154.

Okane I, Srikitikulchai P, Tabuchi Y, Sivichai S, Nakagiri A. 2012. Recognition and characterization of four Thai xylariaceous fungi inhabiting various tropical foliages as endophytes by DNA sequences and host plant preference. Mycoscience 53: 122-132.

Omacini M, Chaneton EJ, Ghersa CM, Müller CB. 2001. Symbiotic fungal endophytes control insect host-parasite interaction webs. Nature. 409:78.

Oono R, Lefevre E, Simha A, Lutzoni F. 2015. A comparison of the community diversity of foliar fungal endophytes between seedling and adult loblolly pines (Pinus taeda). Fungal Biol. 119: 917-928.

Opik M, Moora M, Liira J, Zobel M. 2006. Composition of root-colonizing arbuscular mycorrhizal fungal communities in different ecosystems around the globe. J. Ecol. 94: 778-790

Osono T, Hirose D. 2001. Colonization and lignin decomposition of pine needle littler by Lophodermium pinastri. For. Pathol. 41: 156-162.

Peay KG, Kennedy PG, Talbot JM. 2016. Dimensions of biodiversity in the Earth mycobiome. Nat Rev Microbiol. 14:434. Petrini O. 1991. Fungal endophytes of tree leaves. In: Andrews J, Hirano SS, editors. Microbial ecology of leaves. New York:
Springer-Verlag. p. 179-197.

Petrini O. 1996. Ecological and physiological aspects of host specificity in endophytic fungi. In: Redlin SC, Carris LM, editors. Endophytic Fungi of Grasses and Woody Plants. St Paul, MN: American Phytopathological Society. p. 87-100.

Phongpaichit S, Rungjindamai N, Rukachaisirikul V, Sakayaroj J. 2006. Antimicrobial activity in cultures of endophytic fungi isolated from Garcinia species. FEMS Immunol Med Microbiol. 48: 367-372.

Photita W, Lumyong S, Lumyong P, Hyde KD. 2001. Endophytic fungi of wild banana (Musa acuminate) at Doi Suthep Pui National Park, Thailand. Mycol Res. 105: 1508-1513.

Photita W, Lumyong S, Lumyong P, McKenzie EHC, Hyde KD. 2004. Are some endophytes of Musa acuminata latent pathogens? Fungal Divers. 16: 131-140.

Prihastuti H, Cai L, Chen H, Hyde KD. 2009. Characterization of Colletotrichum species associated with coffee berries in Chiang Mai, Thailand. Fungal Divers. 39: 89-109.

Promputtha L, Lumyong S, Dhanasekaran V, McKenzie E, Hyde K, Jeewon R. 2007. A Phylogenetic Evaluation of Whether Endophytes Become Saprotrophs at Host Senescense. Microb. Ecol. 53: 579-590.

Pulido CR, Bojaca C, Salazar MR, Chaves B. 2008. Node appearance model for Lulo (Solanum quitoense L.) in the high altitude tropics. Biosyst Eng. 101: 383-387.

Quinchia CF, Cabrera CA. 2006. Manual técnico del cultivo del Lulo (Solanum quitoense Lam.) en el departamento de Huila. Gobernación del Huila. Neiva, Huila. Colombia.

Reis BMS, Silva A, Alvarez MR, Oliveira TB, Rodrigues A. 2015. Fungal communities in garden of leafcutter ant Atta cephalotes in forest and cabruca agrosystems of southern Bahia State (Brazil). Fungal Biol. 119: 1170-1178.

Revelo J, Viteri P, Vásquez W, Valverde F, León J, Gallegos P. 2010. Manual del Cultivo Ecológico de la Naranjilla. INIAP, Ecuador.

Rivera-Ordoña FN, Suárez-Sánchez RA, Flores-Bustamante ZR, Gracida-Rodriguez JN, Flores-Cotera LB. 2011. Diversity of endophytic fungi of Taxus globosa (Mexican yew). Fungal Divers. 47: 65-74.

Rogg H. 2000. Manejo integrado de plagas en cultivos de la Amazonía Ecuatoriana. Editorial Abya Yala, Quito, Ecuador.

Rungjindamai N, Pinruan U, Choeyklin R, Hattori T, Jones 
EBG. 2008. Molecular characterization of basidiomycetous endophytes isolated from leaves, rachis and petioles of the oil palm, Elaeis guineensis, in Thailand. Fungal Divers. 33: 139161.

Saikkonen K, Wali P, Helander M, Faeth SH. 2004. Evolution of endophyte-plant symbioses. Trends Plant Sci. 9: 275-280.

Sánchez Márquez S, Bills GF, Zabalgogeazcoa I. 2007. The endophytic mycobiota of the grass Dactylis glomerata. Fungal Divers. 27:171-195.

Sánchez Márquez S, Bills GF, Domínguez-Acuña L, Zabalgogeazcoa I. 2010. Endophytic mycobiota of leaves and roots of the grass Holcus lanatus. Fungal Divers. 41: 115-123.

Santos JM, Vrandečić K, Ćosić J, Duvnjak T, Phillips AJL. 2011. Resolving the Diaporthe species occurring on soybean in Croatia. Persoonia. 27: 9-19.

Santos TT, Leite TS, Queiroz CB, Araujo EF, Pereira OL, Queiroz MV, 2015. High genetic variability in endophytic fungi from the genus Diaporthe isolated from common bean (Phaseolus vulgaris L.) in Brazil. J Appl Microbiol. 120: 388401.

Schadt CW, Martin AP, Lipson DA, Schmidt SK. 2003. Seasonal dynamics of previously unknown fungal lineages in tundra soils. Science. 301:1359-61.

Schoch CL, Seifert KA, Huhndorf S, Robert V, Spouge JL, Levesque CA, Chen W, Bolchacova E, Voigt K, Crous PW, et al. 2012. Nuclear ribosomal internal transcribed spacer (ITS) region as a universal DNA barcode marker for Fungi. Proc Natl Acad. Sci. 109: 6241-6.

Schulz B, Boyle C, Draeger S, Rommert AK, Krohn K. 2002. Endophytic fungi: a source of novel biologically active secondary metabolites. Mycol Res. 106: 996-1004.

Schulz B, Boyle C. 2006. What are endophytes? In: Schulz B, Boyle CJ, Sieber TN, editors. Microbial root endophytes. Berlin: Springer. p. 1-13.

Sebastianes FLS, Lacava PT, Fávaro LCL, Rodrigues MBC, Araújo WL, Azevedo JL, Pizzirani-Kleiner AA. 2011. Genetic transformation of Diaporthe phaseolorum, an endophytic fungus found in mangrove forests, mediated by Agrobacterium tumefaciens. Curr Genet. 58: 21-33.

Sebastianes FL, Cabedo N, El Aouad N, Valente AM, Lacava PT, Azevedo JL, Cortes D. 2012. 3-Hydroxypropionic acid as an antibacterial agent from endophytic fungi Diaporthe phaseolorum. Curr Microbiol. 65: 622-632.

Shannon CE, Weaver W. 1963. The Mathematical Theory of
Communication. Urbana, IL: University of Illinois Press. 144 p.

Sieber T. 2007. Endophytic fungi in forest trees: are they mutualists? Fungal Biol Rev. 21: 75-89.

Simpson EH. 1949. Measurement of diversity. Nature. 163: 688.

Strobel GA. 2002. Rainforest endophytes and bioactive products. Crit Rev Biotechnol. 22:315-33.

Suryanarayanan TS, Wittlinger SK, Faeth SH. 2005. Endophytic fungi associated with cacti in Arizona. Mycol Res. 109: 635-639.

Tamura K, Stecher G, Peterson D, Filipski A, Kumar S. 2013. MEGA6: molecular evolutionary genetics analysis version 6.0. Mol Biol Evol. 30: 2725-2729.

Tejesvi MV, Kini KR, Prakash HS, Subbiah V, Shetty HS. 2007. Genetic diversity and antifungal activity of species of Pestalotiopsis isolated as endophytes from medicinal plants. Fungal Divers. 24: 37-54.

Thomas SE, Crozier J, Aime MC, Evans HC, Holmes KA. 2008. Molecular characterization of fungal endophytic morphospecies associated with the indigenous forest tree, Theobroma gileri, in Ecuador. Mycol Res. 112: 852-860.

Thompson JD, Higgins DG, Gibson TJ. 1994. CLUSTAL W: improving the sensitivity of progressive multiple sequence alignment through sequence weighting, position-specific gap penalties and weight matrix choice. Nucleic Acids Res. 22: 4673-80.

U'Ren JM, Lutzoni F, Miadlikowska J, Arnold AE. 2010. Community analysis reveals close affinities between endophytic and endolichenic fungi in mosses and lichens. Microb Ecol. 60: 340-353.

U'Ren JM, Arnold AE. 2016. Diversity, taxonomic composition, and functional aspects of fungal communities in living, senesced, and fallen leaves at five sites across North America. Peer J 4: e2768.

Vaz ABM, Da Costa AGFC, Raad LVV, Góes-Neto A. 2014. Fungal endophytes associated with three South American Myrtae (Myrtaceae) exhibit preferences in the colonization at leaf level. Fungal Biol. 118: 277-286.

Vega FE, Simpkins A, Aime MC, Posada F, Peterson SW, Rehner SA, Infante F, Castillo A, Arnold AE. 2010. Fungal endophyte diversity in coffee plants from Colombia, Hawaii, Mexico, and Puerto Rico. Fungal Ecol. 3: 122-138. 
Viret O, Petrini O. 1994. Colonisation of beech leaves (Fagus sylvatica) by the endophytes Discula umbrinella (Teleomorph: Apiognomonia errabunda). Mycol Res. 98: 423-432.

White TF, Brunus T, Lee S, Taylor J. 1990. Amplification and direct sequencing of fungal ribosomal RNA genes for phylogenetics,. In: Innis MA, Gelfand DH, Sninsnky FS, White TT, editors. PCR Protocol: A guide to methods and applications. San Diego: Academic Press. p. 315-322.

Wikee S, Cai L, Pairin N, McKenzie EHC, Su YY, Chukeatirote E, Thi HN, Bahkali AH, Moslem MA, Abdelsalam K, Hyde KD. 2011. Colletotrichum species from Jasmine (Jasminum sambac). Fungal Divers. 46: 171-182.

Williamson B. 1994. Latency and quiescence in survival and success of fungal plant pathogens. In: Blackeman JP, Williamson B, editors. Ecology of plant pathogens. Oxford: CAB International. p. 187-207.

Wilson D. 1995. Endophyte: the evolution of a term, and clarification of its use and definition. Oikos. 73: 274-276.

Yuan Z, Chen L. 2014. The role of endophytic fungal individuals and communities in the decomposition of Pinus massoniana needle litter. PLoS ONE. 9: e105911.

Zhang AW, Hartman GL, Curio-Penny B, Pedersen WL, Becker KB. 1999. Molecular detection of Diaporthe phaseolorum and Phomopsis longicolla from soybean seeds. Phytopathol. 89: 796-804.

Zhu Y, Chen H, Fan J, Wang Y, Li Y, Chen J, Fan J, Yang S, Hu L, Leung H, et al. 2000. Genetic diversity and disease control in rice. Nature. 406:718. 